\title{
Performance Monitoring of a Sulphur Recovery Unit: A Real Start- up Plant
}

Ibrahim $\mathrm{AY}^{1,2 *}$

${ }^{1}$ Department of Chemical Engineering, Cairo University, Egypt

${ }^{2}$ Chemical Engineer in Petrochemical and Refining Industries, Egypt

*Corresponding author: Ahmed Y Ibrahim, Department of Chemical Engineering, Cairo University, Giza 12613, Egypt, Tel: +201068585812; Email: yehiawe@hotmail.com

\section{Research Article}

Volume 5 Issue 1

Received Date: March 18, 2021

Published Date: March 29, 2021

DOI: $10.23880 /$ ppej-16000260

\section{Abstract}

A Sulphur recovery unit at a refining plant in the Middle East, which began official production in 2020, treats all acid gas to elemental Sulphur. Acid gas cannot be released into the atmosphere because of stringent environmental regulations. To test some essential parameters, the plant was simulated using a special Sulphur package in HYSYS called SULSIM. One of the most critical keys, the $\left(\mathrm{H}_{2} \mathrm{~S} / \mathrm{SO}_{2}\right)$ ratio, was checked after simulation validation. The optimal ratio is 2 . Any deviation from this ratio results in serious issues in the process, such as catalyst ageing in the reactors. The effect of reducing the ratio from 2 to 0.22 was investigated in a case study. The temperature of the reduction reactor's outlet rose from $279.73^{\circ} \mathrm{C}$ to $314.34^{\circ} \mathrm{C}$, which was higher than normal. The performance of the catalyst was measured on six separate days. The temperature difference and the pressure difference through the bed are the two most important parameters in catalyst monitoring. The $\Delta \mathrm{T}$ designs for the first Claus reactor, second Claus reactor, and Reduction reactor are 51,20 and $24^{\circ} \mathrm{C}$, respectively. $0.04,0.14$, and $0.04 \mathrm{~kg} / \mathrm{cm}^{2} \mathrm{~g}$ are the $\Delta \mathrm{P}$ designs in the first Claus reactor, second Claus reactor, and Reduction reactor, respectively. The actual parameters were found to be in the normal range. Sulphur production is calculated in two ways: by the level of the Sulphur production tank and by calculating the material balance by laboratory analysis. Based on a comparison in four days the calculations are precise because of the levels, and large deviations are revealed by laboratory analysis. The percentage deviation error was found to be $(-36.4,70.7,-7.6,-10.5)$ percent by the laboratory analysis.

Keywords: Catalyst performance; Environmental; Hysys SULSIM package; Sulphur balance; Sulphur recovery unit

Abbreviations: AAG: Amine Acid Gas; ADA: Air Demand Analyzer; ARU: Amine Regeneration Unit; DEA: Diethanolamine; ESD: Emergency Shutdown; LA: Lean Amine; MDEA: Methyl Diethanolamine; NG: Natural Gas; RA: Rich Amine; SOR: Start Of Run; SRE: Sulphur Recovery Efficiency; SRU: Sulphur Recovery Unit; SWS: Sour Water Stripper; SWSAG: Sour Water Stripped Acid Gas; TGT: Tail Gas Treatment; TGTU: Tail Gas Treatment Unit; WHB: Waste Heat Boiler

\section{Introduction}

Because of its toxic and acidic nature, hydrogen sulphide formed in the refinery industry is considered a hazardous pollutant [1-3]. Sulphur Recovery Unit (SRU) plants produce elemental Sulphur from Hydrogen Sulphide [4,5] preventing any emissions of acidic gases that violate environmental legislation in the planet [6-8]. One of the oldest methods for producing Sulphur from Hydrogen Sulphide is the Claus process. Sulphur recovery can be increased in a variety of ways, but the modified Claus process is the most common. One-third of the $\mathrm{H}_{2} \mathrm{~S}$ in the acid gas feed is converted to $\mathrm{SO}_{2}$ in the Thermal Claus section, according to the process's concept. In the Catalytic Claus section, $\mathrm{SO}_{2}$ reacts with the remaining two-thirds of $\mathrm{H}_{2} \mathrm{~S}$ to form Sulphur [9-11]. A thermal reactor Claus furnace and a waste heat boiler (WHB) for heat recovery make up the thermal section. One-third of $\mathrm{H}_{2} \mathrm{~S}$ is oxidised in the thermal reactor via the reaction (Equation 1), while 


\section{Petroleum \& Petrochemical Engineering Journal}

the remaining two-thirds of $\mathrm{H}_{2} \mathrm{~S}$ is reacted with $\mathrm{SO}_{2}$ formed in the thermal reactor to produce Sulphur in the catalytic section (Equation 2). The hot flue gas from the Claus furnace, which includes $\mathrm{COS}$ and $\mathrm{CS}_{2}$ by-products, is cooled by a water stream in the WHB to create high-pressure steam, and elemental Sulphur is recovered after cooling in the Sulphur condenser. The process gas leaving the thermal section is reheated to the proper temperature for the Claus reaction, which produces Sulphur, and the hydrolysis reaction, which transforms $\mathrm{COS}$ and $\mathrm{CS}_{2}$ to $\mathrm{H}_{2} \mathrm{~S}$. To stop Sulphur condensation, the temperature is elevated above the dew point of Sulphur, and the mixture is then passed through the first catalytic reactor, which produces Sulphur through the Claus reaction (Equation 2). The first catalytic reactor also conducts COS and $\mathrm{CS}_{2}$ hydrolysis reactions via the reactions (Equation 3 and Equation 4).

$$
\begin{gathered}
\mathrm{H}_{2} \mathrm{~S}+1.5 \mathrm{O}_{2} \rightarrow \mathrm{SO}_{2}+\mathrm{H}_{2} \mathrm{O}(1) \\
2 \mathrm{H}_{2} \mathrm{~S}+\mathrm{SO}_{2} \rightarrow 3 / 8 \mathrm{~S}_{8}+2 \mathrm{H}_{2} \mathrm{O}(2) \\
\mathrm{CS}_{2}+2 \mathrm{H}_{2} \mathrm{O} \rightleftharpoons \mathrm{CO}_{2}+2 \mathrm{H}_{2} \mathrm{~S}(3) \\
\mathrm{COS}+\mathrm{H}_{2} \mathrm{O} \rightleftharpoons \mathrm{CO}_{2}+\mathrm{H}_{2} \mathrm{~S}(4) \\
2 \mathrm{NH}_{3}+1.5 \mathrm{O}_{2} \rightarrow \mathrm{N}_{2}+3 \mathrm{H}_{2} \mathrm{O}(5)
\end{gathered}
$$

Before the catalytic reactor, there is a reheater, and after the reactor, there is a condenser. The 2-stage has a maximum overall Sulphur recovery efficiency (SRE) of 9395 percent from thermal and catalytic sections. The 3-stage catalytic units have an SRE of 96-98 percent. Figure 1 shows a three stage Sulphur plant. In recent years, environmental regulations have mandated SRE of $99.9 \%$, which can be accomplished by adding the Tail Gas Treatment Unit (TGTU) to the modified Claus process $[7,11-13]$.

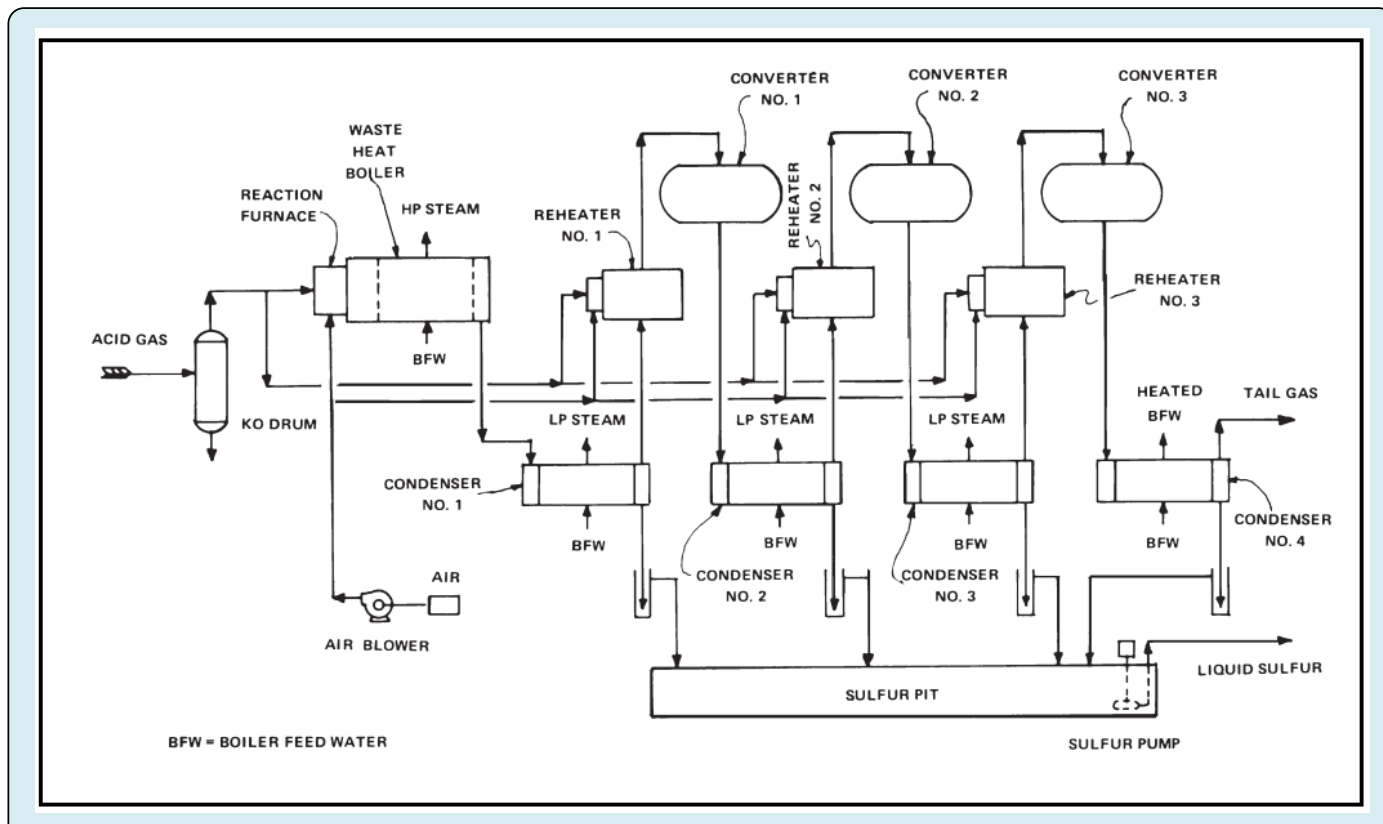

Figure 1: Three-stage Sulphur plant.

The petroleum refining industry is a vital part of the global economy, manufacturing a variety of goods such as chemicals and fuels that are sold on a global scale [14]. However, the sour water provided by the refinery industry contains a variety of hazardous contaminants, the most common of which are hydrogen sulphide $\left(\mathrm{H}_{2} \mathrm{~S}\right)$ and ammonia $\left(\mathrm{NH}_{3}\right)$ [15-17]. Specially designed strippers will eliminate these two contaminants [18-20]. Meanwhile, refineries' sour gas contains hydrogen sulphide $\left(\mathrm{H}_{2} \mathrm{~S}\right)$. As a result, gas sweetening takes place in an amine scrubber facility, where sour gas is exposed to a lean amine (LA) solution in an absorber to absorb $\mathrm{H}_{2} \mathrm{~S}$. After that, the rich amine (RA) with $\mathrm{H}_{2} \mathrm{~S}$ is stripped in an amine regenerator column [21,22].
Diethanolamine (DEA) and methyl DEA (MDEA) amines, in particular, are commonly used in gas sweetening [2326]. When an acidic gas contains both $\mathrm{CO}_{2}$ and $\mathrm{H}_{2} \mathrm{~S}$ and the process must absorb $\mathrm{H}_{2} \mathrm{~S}$ while desorbing $\mathrm{CO}_{2}, \mathrm{MDEA}$ is used. $\mathrm{H}_{2} \mathrm{~S}$ selectivity is higher in DEA than in MDEA [27-29].

An SRU unit at a refining plant in the Middle East, which began commercial production in 2020 , treats all $\mathrm{H}_{2} \mathrm{~S}$ from the refining units to elemental Sulphur. Sour Water Stripped Acid Gas (SWSAG) and Amine Acid Gas (AAG) are the two types of acid gas that feed the SRU plant. Sour water stripping unit 1 (SWS1) and sour water stripping unit 2 (SWS2) provide the SWSAG. Amine Regeneration Unit1 (ARU1) and Amine 


\section{Petroleum \& Petrochemical Engineering Journal}

Regeneration Unit2 (ARU2) provide the AAG. The $\mathrm{H}_{2} \mathrm{~S}$ feed to the SRU is delivered by the overheads from the units. This paper discusses the significance of the $\left(\mathrm{H}_{2} \mathrm{~S} / \mathrm{SO}_{2}\right)$ ratio, as well as some actual issues that may arise during start-up, such as when the TGTU is aligned. It also explains how to calculate real Sulphur production by supplying a material balance from the factory and how to monitor catalyst deactivation.

\section{Process Description}

Sulphur is recovered from Amine Acid Gas and Sour Water Stripper Acid Gas using the Sulphur Recovery Unit (SRU) and Tail Gas Treatment Unit (TGTU). The SRU plant is made up of several sections. The SRU feed characteristics are shown in Table 1.

\begin{tabular}{|c|c|c|c|}
\hline \multicolumn{2}{|c|}{ Stream Description } & Amine Acid Gas & Sour Water Stripper Acid Gas \\
\hline Property & Unit & industrial & industrial \\
\hline Temperature & ${ }^{\circ} \mathrm{C}$ & 55 & 0.77 \\
\hline Pressure & $\mathrm{Kg} / \mathrm{cm}^{2} \mathrm{~g}$ & 0.75 & 3674 \\
\hline Flow & $\mathrm{kg} / \mathrm{h}$ & 11975 & 0.000 \\
\hline \multicolumn{2}{|c|}{ Component } & 0.003 & 0.339 \\
\hline \multicolumn{2}{|c|}{$\mathrm{H}_{2}$} & 0.083 & 0.334 \\
\hline $\mathrm{H}_{2} \mathrm{O}$ & 0.912 & 0.000 \\
\hline $\mathrm{H}_{2} \mathrm{~S}$ & 0.001 & 0.327 \\
\hline $\mathrm{CH}_{4}$ & - & \\
\hline $\mathrm{NH}_{3}$ & & \\
\hline
\end{tabular}

Table 1: Sulphur recovery unit feed characteristics.

\section{Claus Section}

The Thermal Claus Section and the Catalyst Claus Section compose the Claus Section. The Claus process is utilized in acid gas streams that mainly contain $\mathrm{H}_{2} \mathrm{~S}$ and $\mathrm{NH}_{3}$. Onethird of the $\mathrm{H}_{2} \mathrm{~S}$ in the acid gas feed is converted to $\mathrm{SO}_{2}$ in the Thermal Claus Section, according to the process's concept. In the Catalyst Claus section, $\mathrm{SO}_{2}$ reacts with the remaining two-thirds of $\mathrm{H}_{2} \mathrm{~S}$ to form Sulphur.

\section{Thermal Reactor}

The SWS Acid Gas, along with a portion of the Amine Acid Gas and all of the combustion air, is fed to the Thermal Reactor's Main Burner. The complement of Amine Acid Gas is fed to the Thermal Reactor's second zone to keep the first zone's flame temperature high enough to ensure maximum $\mathrm{NH}_{3}$ destruction. The first zone's adiabatic flame temperature is estimated to be between $1350^{\circ} \mathrm{C}$ and $1450^{\circ} \mathrm{C}$. The air supplied to the main burner is precisely enough to complete the oxidation of all hydrocarbons and ammonia present in the total feed gases, as well as to burn as much $\mathrm{H}_{2} \mathrm{~S}$ as is needed to achieve an $\left(\mathrm{H}_{2} \mathrm{~S} / \mathrm{SO}_{2}\right)$ ratio of $2: 1$ in the Claus tail gas.

First and second Claus reactors: First and Second Claus Reactors: The process stream is indirectly heated to the optimum temperature for catalytic conversion (about $240^{\circ} \mathrm{C}$ ) in the first Reactor Reheater by high-pressure steam from Claus WHB before entering the Claus reactor. In the
Claus Reactor, the reaction between $\mathrm{H}_{2} \mathrm{~S}$ and $\mathrm{SO}_{2}$ is carried out until equilibrium is reached over a catalyst bed; due to exothermic reactions, the gas leaving the Claus reactor has a temperature of about $300^{\circ} \mathrm{C}$. Around $90 \%$ of the first Claus Reactor is loaded with titanium (Ti) catalyst, which improves the $\mathrm{COS}$ and $\mathrm{CS}_{2}$ hydrolysis reaction. The effluent gas from the first Claus Reactor is then directed to the second Sulphur Condenser, where it is condensed and drained to the Sulphur Drum through a Sulphur seal. The process gas flow from the second Sulphur Condenser is reheated to $200^{\circ} \mathrm{C}$ with HP steam and fed to the second Claus Reactor, which is filled with alumina catalyst. As the turndown condition approaches, it is recommended that the preheating temperature be increased to about $207^{\circ} \mathrm{C}$ to hold the outlet tail gas slightly above the Sulphur dew point. Before being sent to the TGT section, the gas from the second reactor passes through the Final Sulphur Condenser. Figure 2 shows a simplified Claus section.

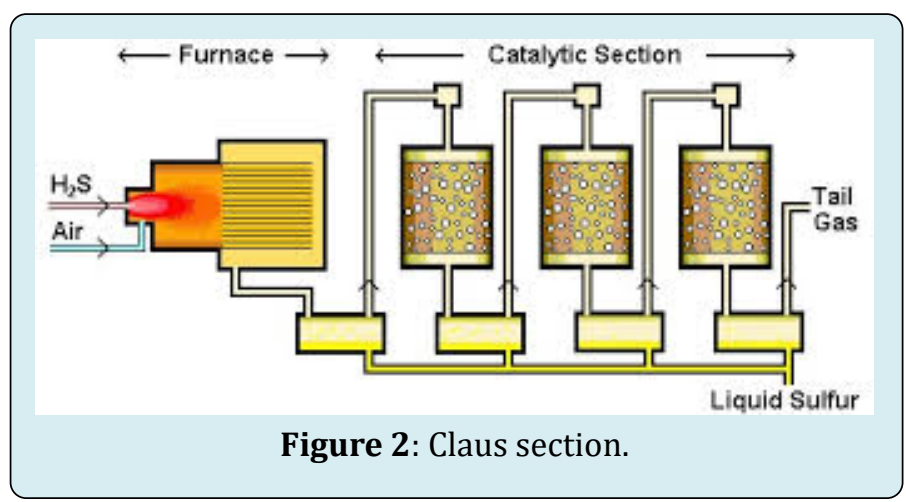




\section{Tail Gas Treatment Unit (TGTU)}

The SRU's tail gas will be treated further in a single tail gas treating unit (TGTU) to boost $\mathrm{H}_{2} \mathrm{~S}$ conversion to Sulphur to $99.5 \mathrm{wt} \%$. The Sulphur compounds from the tail gas from the Claus section $\left(\mathrm{SO}_{2}, \mathrm{COS}, \mathrm{CS}_{2}\right)$ are transformed to $\mathrm{H}_{2} \mathrm{~S}$ in the hydrogenation reactor (reduction rector) using $\mathrm{H}_{2}$. The $\mathrm{H}_{2} \mathrm{~S}$ is converted, cooled, and absorbed by lean amine before being recycled to SRU feed for reprocessing. Figure 3 shows the tail gas treatment section.



\section{Degassing Section}

The SRU contains soluble $\mathrm{H}_{2} \mathrm{~S}$ and $\mathrm{H}_{2} \mathrm{Sx}$ in its liquid Sulphur (hydrogen polysulphides). Due to its toxicity and explosion risks, the presence of $\mathrm{H}_{2} \mathrm{~S}$ in the liquid during
Sulphur conveyance and handling may trigger safety and environmental issues. As a result, liquid Sulphur is degassed to lower the $\mathrm{H}_{2} \mathrm{~S}$ content to a healthy amount of $10 \mathrm{ppm}$ by weight. The degassing segment is depicted in Figure 4.

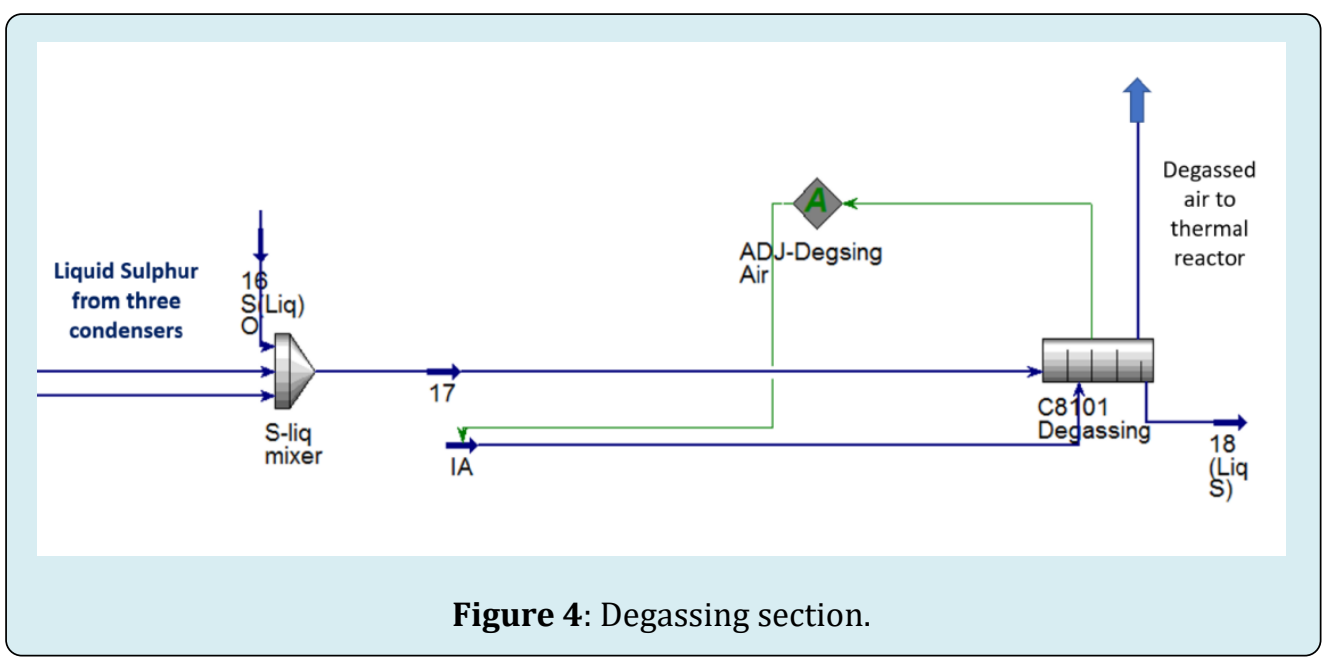

\section{Solidification Section}

The liquid Sulphur is pumped to the Sulphur Solidification Section after it has been degassed. The liquid Sulphur delivered to the solidification device is solidified using the pastillation process, which involves rotating machines delivering liquid droplets that are solidified onto steel belts using a closed-loop circulating cold water. A collecting conveyor gathers the solid pastilles/granules, which are then raised into two silos by a bucket elevator and a reversible conveyor. The Sulphur pastilles are loaded directly onto the truck from the silos. 


\section{Petroleum \& Petrochemical Engineering Journal}

\section{Incineration Section}

To convert all Sulphur compounds, present in the tail gas emitted by the Claus and TGT units into $\mathrm{SO}_{2}$, the tail gas must be incinerated. A stack discharges the flue gas emitted by the incineration to the atmosphere. Since all of the fuel components contained in tail gas are at very low concentrations, the ignition temperature is much higher than the real tail gas temperature; thus, tail gas combustion must be accompanied by natural gas combustion. During normal operation, the temperature of the Incineration combustion chamber is $650^{\circ} \mathrm{C}$. This temperature is needed to ensure nearly complete combustion of $\mathrm{H}_{2} \mathrm{~S}$ and other Sulphur compounds in the tail gas (less than 10 ppm residual $\mathrm{H}_{2} \mathrm{~S}$ is expected). The incineration segment is shown in Figure 5.

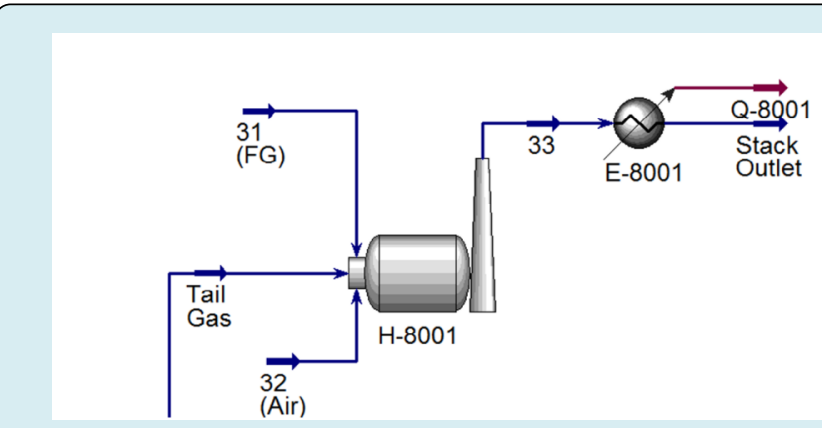

Figure 5: Incineration section.

\section{Start-up Procedures of the SRU}

The steps for the startup are the following: heating-up phase and acid gas operation

\section{Heating-up Phase}

Ensure minimum incinerator required temperature $\left(500^{\circ} \mathrm{C}\right)$, TGT section is by-passed (under nitrogen circulation), degassing section start-up (ready to receive liquid Sulphur), thermal reactor and Claus section start-up (heating up with natural gas).

\section{Start-up with Acid Gas}

The general start-up procedures with acid gas are as follow: Switching from natural gas to amine acid gas, SWS acid gas stream is introduced to the thermal reactor, close TGT section by-pass (Claus train and TGT section lined up), operating conditions adjustment, acid condensate transfer, Sulphur degassing start-up.

\section{Regenerator Section \& TGT Start-up (can be performed independently)}

The general start-up procedures for the TGT section are as follow:

Formulated amine solution loading and cold circulation, Amine regenerator reboiler start-up, TGT start-up, close TGT section by-pass (Claus train and TGT section lined up)

\section{General Preparation of SRU}

The general preparation procedures for SRU start-up are as follows:

All the equipment, instrumentation, control system, ESD system, firefighting system ready for the Unit Start-up, all utilities are available according to the design basis and ready to start, Steam tracing and jacketing to be in operation and Steam traps shall work properly.

\section{Incinerator Start-up}

With an incinerator flue gas temperature above $500^{\circ} \mathrm{C}$, it is possible to send the fuel gas (NG) combustion products coming from the Claus sections. To ensure thermal oxidation of $\mathrm{H}_{2} \mathrm{~S}$, during acid gas operation, the tail gas from the Claus section can be sent to the Incinerator only if the combustion chamber temperature is higher than $600^{\circ} \mathrm{C}$. During normal operation with TGT online, incinerator temperature shall be at least $650^{\circ} \mathrm{C}$.

\section{Sulphur Degassing Section Start-up}

The following items shall be considered before the degassing section start-up:

Ensure steam tracing and steam jacketing systems are in operation, Incinerator is working properly with a combustion temperature $>600{ }^{\circ} \mathrm{C}$ and $\mathrm{O}_{2}$ content $>2 \%$ and that the ambient $\mathrm{H}_{2} \mathrm{~S}$ analyzers are working properly.

\section{Claus Start-up}

With the purpose to reduce the emission to the atmosphere, Acid Gas can be introduced in the Claus burner when the natural gas combustion is stable and at a temperature of about $1000-1150^{\circ} \mathrm{C}$.

Cold mode (first start-up no Sulphur on the catalyst beds): The burner light-on is with natural gas and excess air, as the natural gas increases flame temperature higher than normal ones, quench steam is added to mitigate flame temperature.

Hot mode (start-up after the shut-down presence of Sulphur in the plant): The burner light-on is with natural gas and stochiometric air, quench steam is added to mitigate flame temperature. When the temperature of the thermal reactor is at least $1000-1150^{\circ} \mathrm{C}$, the operator shall start to gradually open the acid gas. fuel gas flow rate as to be 


\section{Petroleum \& Petrochemical Engineering Journal}

decreased accordingly.

Natural gas combustion resume: This mode is performed during light-on and heating-up of Claus section, before the start-up with acid gas before any operation with NG, check with a portable explosimeter that the area around the burners is free from combustible gases. Before any operation with NG, it is mandatory to receive the last gas analysis. With the new analysis, if necessary, the operator at Distributed Control System (DCS) shall adjust the gas molecular weight and/or the corresponding (NG/air) ratio. During NG combustion, the adiabatic flame temperature could raise to $2000^{\circ} \mathrm{C}$. The adiabatic flame temperature must be kept below the maximum operating temperature of refractory material lining the thermal reactor. Quench steam can be fed at any time during NG stable operation to keep the flame temperature below $1350^{\circ} \mathrm{C}$.

NG type of combustion with excess air: This mode shall be avoided during the presence of Sulphur in the plant. the Sulphur reacts with free oxygen in a highly exothermic reaction to form $\mathrm{SO}_{2}$. the localized temperature increase with the consequences of (catalyst aging and thermodegradation).

NG type of combustion with defect air: This mode shall be avoided because of coke formation. Coke tends to be absorbed/filtered on the catalytic beds of Claus Reactors (catalyst fouled and pressure drops increase).

NG type of combustion with stoichiometric air: This mode shall be applied in case of normal operation or any startup while Sulphur is deposited on the catalyst. All hydrocarbons gas must be burnt to $\mathrm{CO}_{2}$ and $\mathrm{H}_{2} \mathrm{O} . \mathrm{O}_{2}$ and $\mathrm{CO}$ content in the flue gas can be controlled through a portable $\left(\mathrm{O}_{2} / \mathrm{CO}\right)$ analyzer $(<0.4 \% \mathrm{vol})$.

\section{Amine Recovery System Start-up}

This step may be performed separately from the Claus section or in line with the Claus section start-up.

MDEA solution loading and circulation: Before starting up the Tail Gas Absorber of the TGT section, it is necessary to commission the amine circuit and to put on stream the regeneration section. It is assumed that the Absorber is still isolated from the reduction part of the section. The Amine circuit of the TGT section must be carefully purged and all the present air shall be dispatched away before loading the Formulated MDEA solution (oxygen can deactivate the amine). The amine circuit purging is generally accomplished employing steam (steam out) or by nitrogen. All the amine circuit of the TGT section is maintained under slight nitrogen pressure. When all the air (as oxygen) is completely removed from the amine circuit, the amine loading operation in the equipment unit shall be carried out. Perform a cold MDEA solution circulation from absorber to regenerator. Keeps this cold circulation for some hours controlling the correct working of all instruments and the increasing of fouling in Filters.

Regenerator startup: Start-up the regenerator tower, now the amine circuit is all working, and the Absorber tower is ready to accept the tail gas coming from the TGT section.

Tail gas treatment up to quench tower start-up: Before start-up of this section, the following items shall be assured: TGT is in hot standby, the quench tower system is working properly, each Claus train is fully excluded from the TGT Section: the TGT Section by-pass valve is open, and the TGT Section inlet valve is closed (The Claus tail gas is directed to incinerator), Nitrogen inerting to maintain TGT under slightly positive pressure, recycle Gas Blower is in operation, hydrogenation reactor is heated-up and presulphiding procedure of TGT catalyst has been completed (It is done in the first start-up to activate the catalyst.

TGT line-up: The DCS operator can start closing the TGT bypass valve and opening the inlet valve to TGT Section, using the relevant remote controllers. The diversion procedure shall be realized as slowly as possible to avoid problems in the Claus and TGT Section. After the TGT has been linedup with the Claus tail gas, stop the recycle gas blower. The Absorber is still isolated from the TGT Section and under an inert atmosphere (no Oxygen is present in any piece of equipment); maintain the TGT Section slightly pressurized with Nitrogen $\left(0.1 \mathrm{~kg} / \mathrm{cm}^{2} \mathrm{~g}\right)$. Make sure that the Amine Solution flow rate is set at the design flow and that the Lean Amine temperature is $43^{\circ} \mathrm{C}$ maximum; Make sure that the Amine Regenerator Unit is working properly (monitoring pressure, temperature and level of the Regenerator); Stop feeding Nitrogen to the Absorber; Gradually admit the Claus tail gas into the TGT Section (diversion procedure); The Hydrogen analyzer and Hydrogen control system should be working in the automatic mode. Make sure that the Hydrogen in the stream leaving the Quench Tower is of about $(2.5 \div 3 \%$ vol) on a wet basis; Make sure that the temperature of the gas entering the Hydrogenation Reactor is maintained at $240^{\circ} \mathrm{C}$; As soon as the $\mathrm{SO} 2$ starts to be converted in the Reduction Reactor, the reactor outlet temperature will increase; Make sure that the controller PIC acting on the Pressure Control Valve PV on the Absorber by-pass line works properly discharging into the Thermal Incinerator the reduced gas at about $0.1 \mathrm{~kg} / \mathrm{cm}^{2} \mathrm{~g}$; Increase the Claus Tail Gas flow rate to the TGT Section continuing the diversion procedure; When the tail gas flow rate to the Hydrogenation Reactor is at least $30 \%$ of the design one shut down the TGT Recycle Gas Blower; When the Recycle Blower is shut, gradually introduce the entire available flow rate of the Claus Tail Gas from the Claus Section by continuing the diversion procedure closing the control valve to Incinerator 


\section{Petroleum \& Petrochemical Engineering Journal}

and opening the control valve to TGT Section; Make sure that the temperature controller follows the reactor inlet gas temperature and that the $\mathrm{H} 2$ concentration downstream the Quench Tower is of about $(2.5 \div 3 \%)$ vol. on a wet basis; As soon as the TGT Recycle Gas Blower has been shut-down and the Claus Tail Gas circulation in the Quench Section has been stabilized, close the inlet recycle line valve and purge carefully the recycle line using the relevant Nitrogen purging connection; Gradually open the Absorber by-pass valve, to send the reduced gas in the Absorber. This operation should be completed in few minutes; When the Absorber by-pass valve is open, reset the PIC on the top of Quench Tower at operating pressure (higher than the actual pressure); Verify the correct operation of the Absorber: make sure that the Claus Tail Gas contains only a small portion of residual $\mathrm{H}_{2} \mathrm{~S}$ (by Dräger tubes or by laboratory analysis). Now all Claus and TGT Section are on stream treating the Amine Acid Gas and SWS Acid Gas.

\section{Materials and Methods}

\section{Simulation Sections}

For plant simulation, the researchers used the Aspen HYSYS V.11 Sulphur SULSIM package. The simulation was then validated against plant data before being used in case studies. Figure 6 shows the output from the SRU simulation. Ibrahim described the simulation steps in details in the article "Performance Assessment of a Sulphur Recovery Unit" [30].

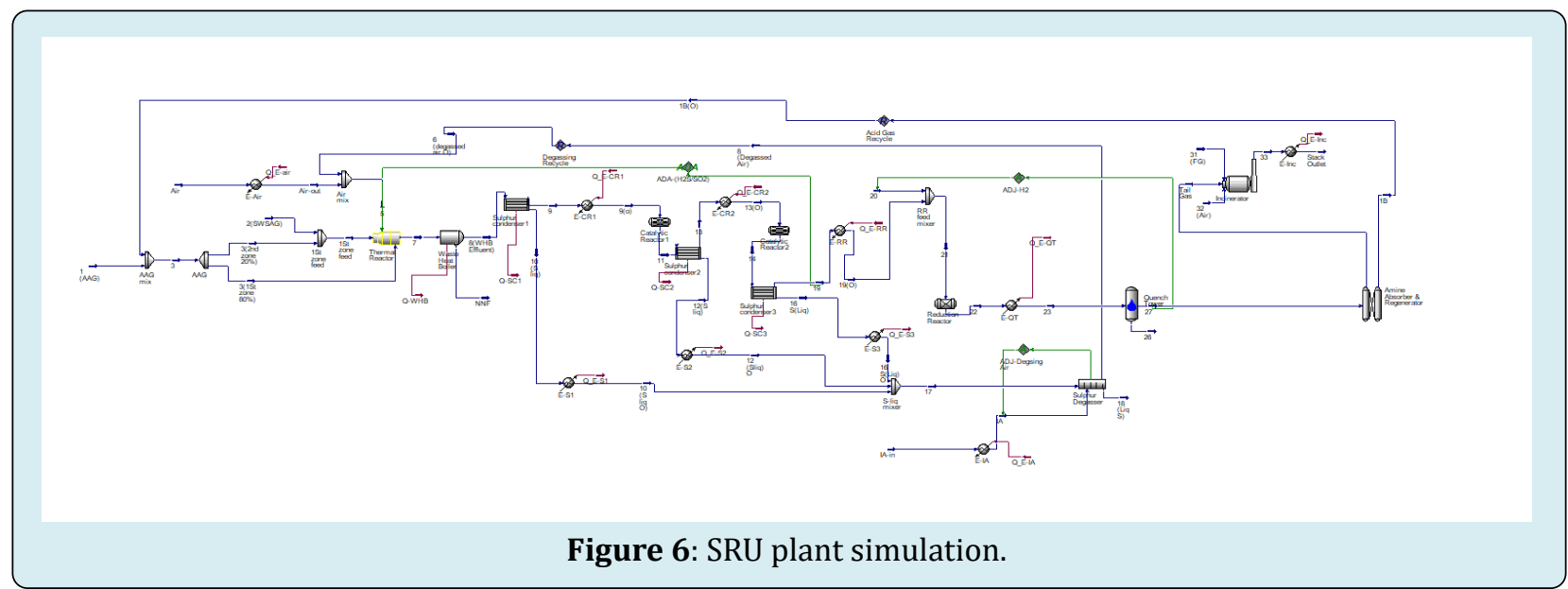

\section{Validation Step}

Industrial data were compared to simulation results for validation. When comparing base case simulation and industrial results, the comparison focuses on the outlet product Sulphur stream and flue gases from the stack stream because the plant's goal is to produce Sulphur while adhering to environmental regulations. The validation results are shown in Table 2.

\begin{tabular}{|c|c|c|c|c|c|c|c|}
\hline \multicolumn{2}{|c|}{ Stream Description } & \multicolumn{3}{|c|}{ Liquid Sulphur Product } & \multicolumn{3}{|c|}{ Flue Gas To Stack } \\
\hline property & Unit & industrial & Simulation & $\%$ error & industrial & Simulation & \% error \\
\hline Temperature & ${ }^{\circ} \mathrm{C}$ & 135 & 135 & - & 652 & 652 & - \\
\hline Pressure & $\mathrm{kg} / \mathrm{cm}^{2} \mathrm{~g}$ & 0.01 & 0.01 & - & 0.01 & 0.01 & - \\
\hline Flow & $\mathrm{kg} / \mathrm{h}$ & 12430 & 12438 & 0.1 & 41283 & 43002 & 4.2 \\
\hline \multicolumn{2}{|c|}{ Component } & \multicolumn{6}{|c|}{ mole fraction } \\
\hline \multicolumn{2}{|c|}{$\mathrm{H}_{2}$} & 0.000 & 0.000 & 0.0 & 0.012 & 0.011 & 8.3 \\
\hline \multicolumn{2}{|c|}{$\mathrm{H}_{2} \mathrm{O}$} & 0.000 & 0.000 & 0.0 & 0.116 & 0.120 & 3.6 \\
\hline \multicolumn{2}{|c|}{$\mathrm{CO}$} & 0.000 & 0.000 & 0.0 & 0.000 & 0.000 & 0.0 \\
\hline \multicolumn{2}{|c|}{$\mathrm{N}_{2}$} & 0.000 & 0.000 & 0.0 & 0.828 & 0.819 & 1.0 \\
\hline \multicolumn{2}{|c|}{$\mathrm{O}_{2}$} & 0.000 & 0.000 & 0.0 & 0.020 & 0.020 & 1.4 \\
\hline \multicolumn{2}{|c|}{$\mathrm{CO}_{2}$} & 0.000 & 0.000 & 0.0 & 0.025 & 0.023 & 5.3 \\
\hline \multicolumn{2}{|c|}{ Sliq } & 1.000 & 1.000 & 0.0 & 0.000 & 0.000 & 0.0 \\
\hline \multicolumn{2}{|c|}{$\mathrm{NH}_{3}$} & 0.000 & 0.000 & 0.0 & 0.000 & 0.000 & 0.0 \\
\hline
\end{tabular}

Table 2: Validation results [31]. 


\section{Petroleum \& Petrochemical Engineering Journal}

\section{$\left(\mathrm{H}_{2} \mathrm{~S} / \mathrm{SO}_{2}\right)$ Ratio versus Outlet Temperature from the Hydrogenator Case Study}

In HYSYS, a new case study is chosen. The $\left(\mathrm{H}_{2} \mathrm{~S} / \mathrm{SO}_{2}\right)$ ratio is chosen as the independent variable, while the temperature of the hydrogenator's outlet is chosen as the dependent variable. The ratio's range is set between ( 2 and 0 ); a lower ratio implies a higher $\mathrm{SO}_{2}$ concentration, which can trigger a number of operational issues. The standard $\left(\mathrm{H}_{2} \mathrm{~S} / \mathrm{SO}_{2}\right)$ ratio is 2 , and the problems with high $\mathrm{SO}_{2}$ content in the tail gas inlet to the hydrogenator are summarized in Table 3.

\begin{tabular}{|c|c|}
\hline Cause & Effect \\
\hline \multirow{4}{*}{$\begin{array}{c}\text { High } \mathrm{SO}_{2} \text { content } \\
\text { in tail gas }\end{array}$} & $\begin{array}{c}\text { Exothermic damages for } \\
\text { temperatures } 420^{\circ} \mathrm{C} \text { with } \\
\text { deactivation of the catalyst }\end{array}$ \\
\cline { 2 - 2 } & $\begin{array}{c}\text { Low pH on the quench tower } \\
\text { downstream the reduction reactor } \\
\text { due to the formation of } \mathrm{SO}_{2} \text { salts }\end{array}$ \\
\cline { 2 - 2 } & $\begin{array}{c}\text { Gray Sulphur formation at the bottom } \\
\text { of the quench column }\end{array}$ \\
\cline { 2 - 2 } & Possible amine degradation \\
\hline
\end{tabular}

Table 3: $\mathrm{High}_{2}$ content in tail gas inlet to reduction reactor problems.

\section{Catalyst Monitoring Parameters}

Catalyst is monitored based on two key parameters: temperature and pressure differences between reactor inlet and outlet. Claus reactor 1 , Claus reactor 2, and the Hydrogenator reactor are the three main reactors that require catalyst monitoring.

\section{Sulphur Material Balance}

The Sulphur balance in any stream is determined as follows: the stream's flow is measured using an instrumentation device and converted to $\mathrm{kg} / \mathrm{h}$. Laboratory analysis determines the $\mathrm{H}_{2} \mathrm{~S}$ concentration in weight percent. To calculate $\mathrm{H}_{2} \mathrm{~S}$ flow $\mathrm{kg} / \mathrm{h}$, multiply the $\mathrm{H} 2 \mathrm{~S}$ concentration wt. percent by the stream flow $(\mathrm{kg} / \mathrm{h})$. Since $\mathrm{H}_{2} \mathrm{~S} \rightarrow \mathrm{H}_{2}+\mathrm{S}$ and $\mathrm{H}_{2} \mathrm{~S}$ has a molecular weight of 34 while Sulphur has a molecular weight of 32 , the Sulphur weight $(\mathrm{kg} / \mathrm{h})$ is calculated by multiplying $\mathrm{H}_{2} \mathrm{~S}(\mathrm{~kg} / \mathrm{h})$ by $(32 / 34)$.

\section{Results and Discussions}

\section{$\left(\mathrm{H}_{2} \mathrm{~S} / \mathrm{SO}_{2}\right)$ Ratio versus Outlet Temperature from the Hydrogenator Case Study Results}

The optimum $\left(\mathrm{H}_{2} \mathrm{~S} / \mathrm{SO}_{2}\right)$ operation ratio is $(2: 1)$, and any variation in this ratio can cause serious problems in the overall process and the TGTU section. During Start-up mode, natural gas is used to heat the process until it reaches the appropriate temperature in the reaction furnace, which is $1350{ }^{\circ} \mathrm{C}$. After that, acid gases are added to the reaction furnace without the TGTU section being lined up. After adjusting the ratio $\left(\mathrm{H}_{2} \mathrm{~S} / \mathrm{SO}_{2}\right)$ to 2 , the reduction reactor can be lined up. The reactions in the TGTU section's reduction reactor are extremely exothermic. In a typical ratio, the reduction reactor's outlet temperature is about $280{ }^{\circ} \mathrm{C}$. Catalyst sintering occurs when the temperature reaches 400 degrees Celsius. The effect of lowering this ratio on the reduction reactor's outlet temperature is shown in Table 4.

\begin{tabular}{|c|c|}
\hline $\begin{array}{c}\left(\mathbf{H}_{2} \mathbf{S} / \mathbf{S O}_{2}\right) \\
\text { ratio }\end{array}$ & $\begin{array}{c}\text { Outlet Temperature from Reduction } \\
\text { Reactor }\end{array}$ \\
\hline 2.00 & 279.73 \\
\hline 1.78 & 281.00 \\
\hline 1.56 & 282.53 \\
\hline 1.33 & 284.45 \\
\hline 1.11 & 286.93 \\
\hline 0.89 & 290.26 \\
\hline 0.67 & 295.23 \\
\hline 0.44 & 303.58 \\
\hline 0.22 & 314.34 \\
\hline
\end{tabular}

Table 4: $\left(\mathrm{H}_{2} \mathrm{~S} / \mathrm{SO}_{2}\right)$ ratio relation versus outlet temperature from reduction reactor.

The ratio was reduced from 2.00 to 0.22 , which increased the outlet temperature to $314.34^{\circ} \mathrm{C}$. More heating to 400 degrees Celsius will result in catalyst sintering. As shown in Table 5, sulphur compounds mole percent inlet to the reduction reactor is in small amounts. In other words, since the reduction reactor is unable to handle large amounts of these materials, in this case, the TGT section is bypassed the tail gas from the Claus section is sent to the incinerator. High $\mathrm{SO}_{2}$ inlet to the reduction reactor can affect the catalyst, resulting in high incinerator emissions.

\begin{tabular}{|c|c|}
\hline Component & Mole \% \\
\hline $\mathrm{H}_{2} \mathrm{~S}$ & 0.5950 \\
\hline $\mathrm{SO}_{2}$ & 0.2975 \\
\hline $\mathrm{COS}$ & 0.0002 \\
\hline $\mathrm{CS}_{2}$ & 0.0003 \\
\hline
\end{tabular}

Table 5: Sulphur compounds inlet to the reduction reactor.

The $\left(\mathrm{H}_{2} \mathrm{~S} / \mathrm{SO}_{2}\right)$ ratio takes a long time to adjust to 2 after switching from natural gas to acid gas mode. During this time, the TGT is bypassed and the tail gas from the Claus section is sent to the incinerator. Figures 7-10 are gathered from actual four startups 


\section{Petroleum \& Petrochemical Engineering Journal}

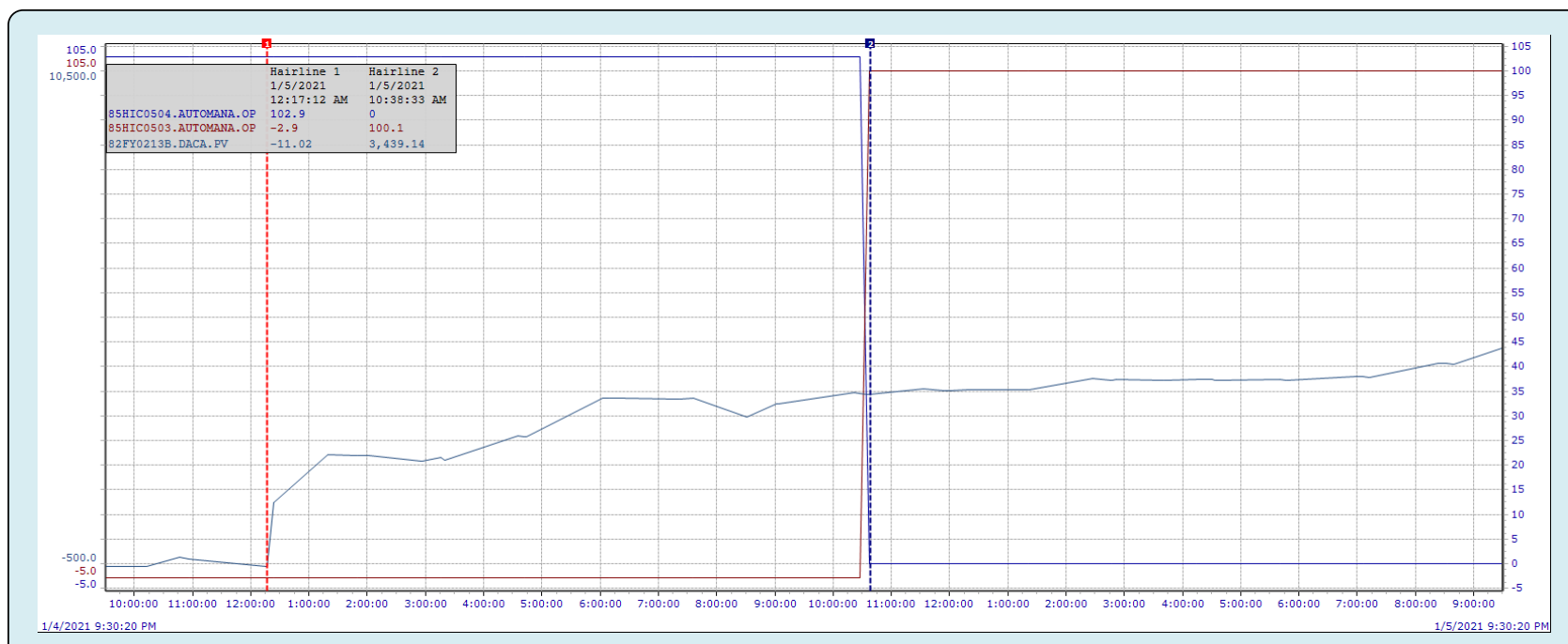

Figure 7: Startup 1 timing between starting acid gas to Claus and lining up TGT.

Figure 7 shows that the switching time between introducing the acid gas to the Claus (red color line) and the

lining up of the TGT took 11 hours.

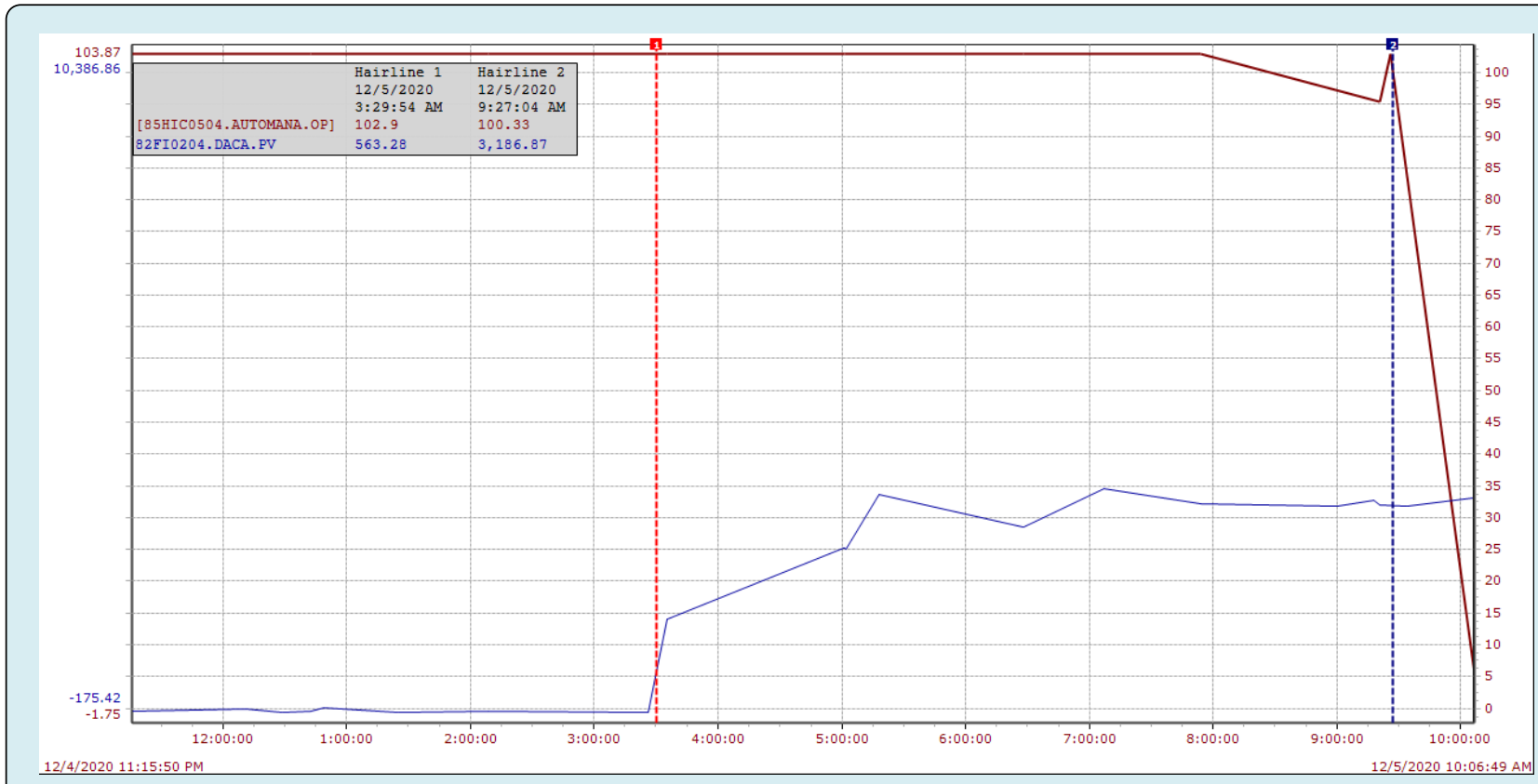

Figure 8: Startup 2 timing between starting acid gas to Claus and lining up TGT.

Figure 8 shows that the switching time between introducing the acid gas to the Claus (red color line) and the

lining up of the TGT took 6 hours. 


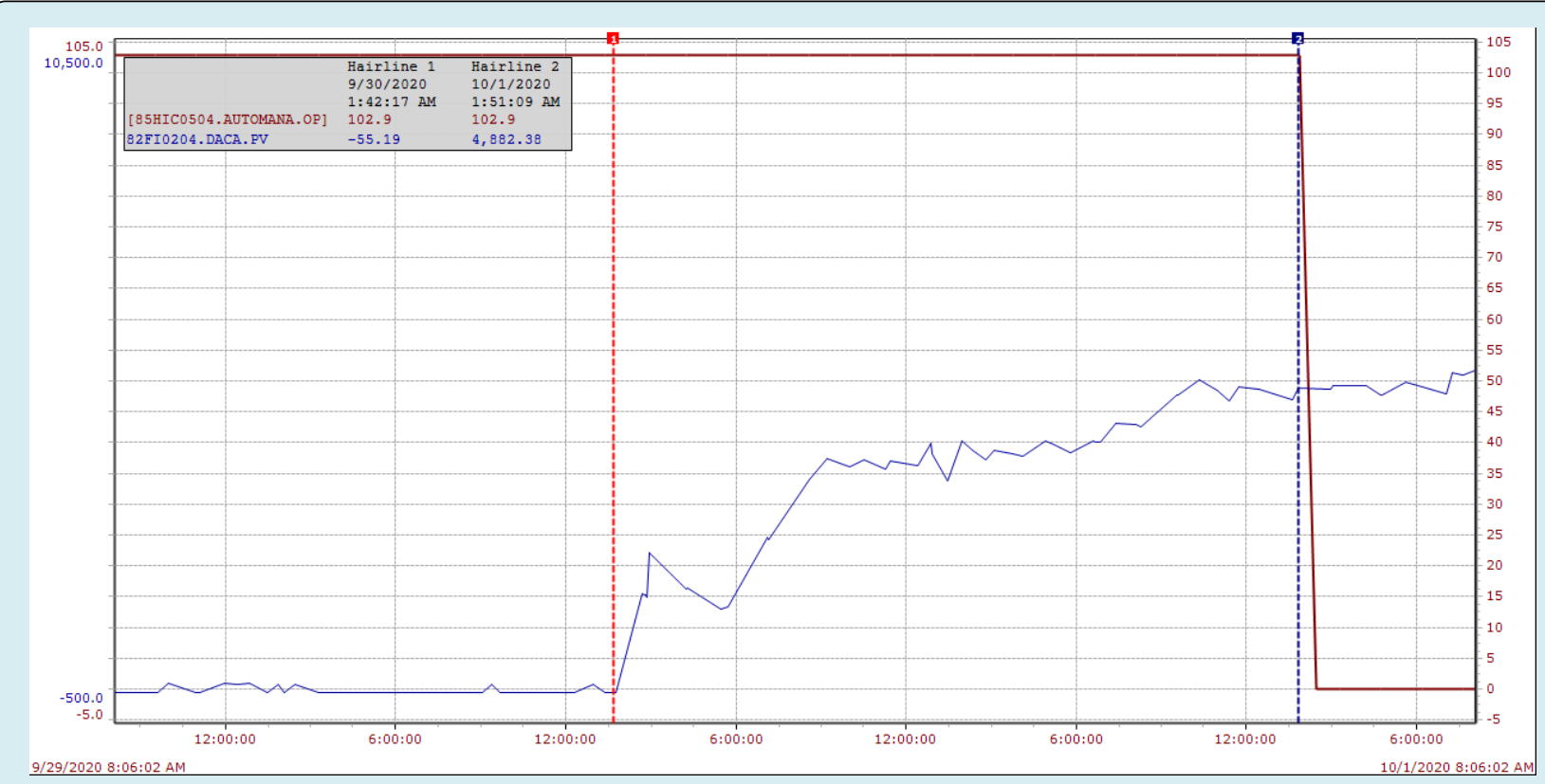

Figure 9: Startup 3 timing between starting acid gas to Claus and lining up TGT.

Figure 9 shows that the switching time between introducing the acid gas to the Claus (red color line) and the

lining up of the TGT took 24 hours.

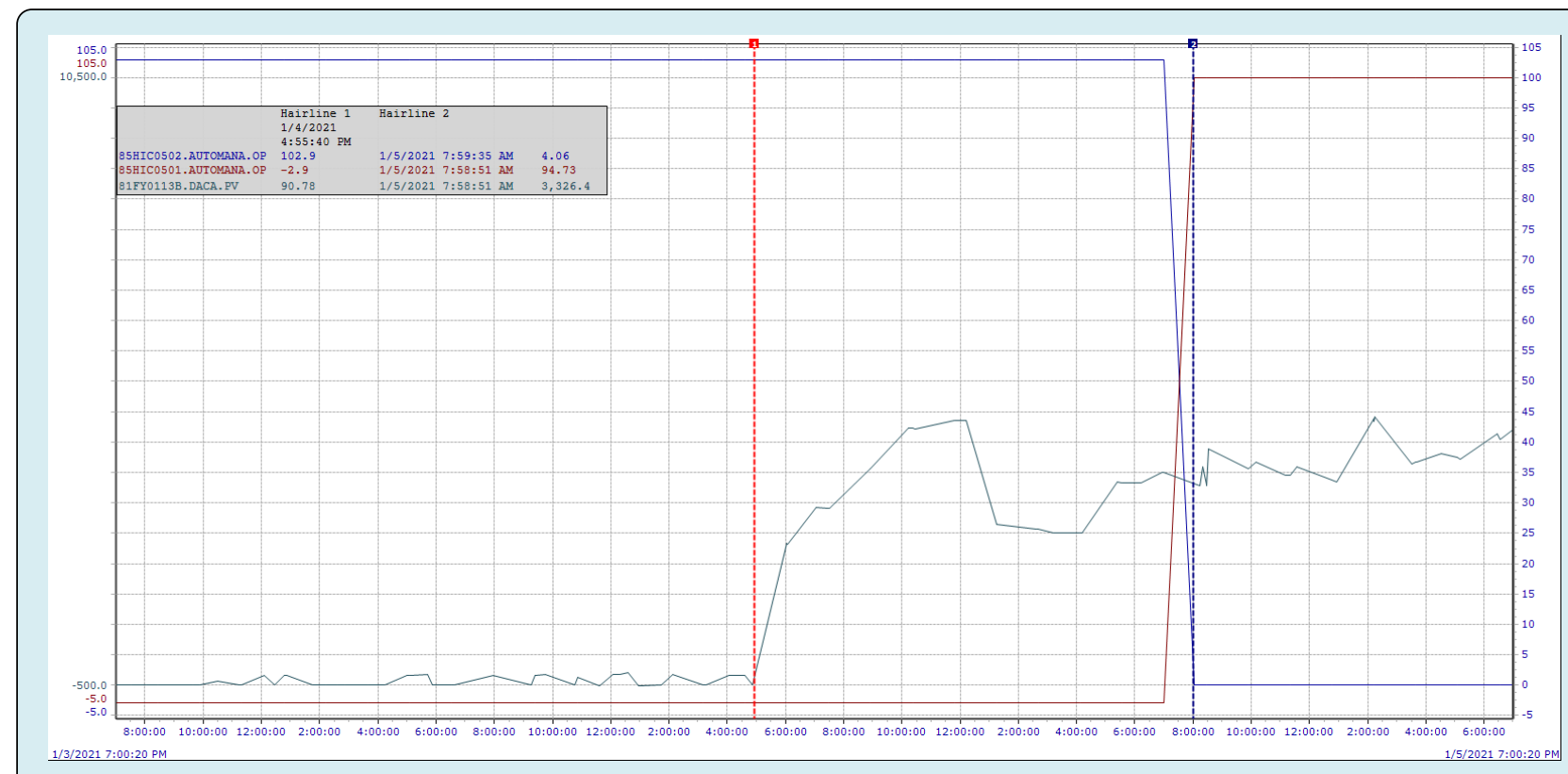

Figure 10: Startup 4 timing between starting acid gas to Claus and lining up TGT.

Figure 10 shows that the switching time between introducing the acid gas to the Claus (red color line) and the lining up of the TGT took 14 hours. The purpose of the four startups timing variance is to ensure that the ratio is set to 2 and that the thermal reactor flame temperature is at the optimal value of $1350^{\circ} \mathrm{C}$ to ensure that ammonia is destroyed in the reaction furnace according to equation 5.

\section{Catalyst Performance}

The difference in pressures and temperatures between the reactor inlets and outlets are the two most important parameters to consider when evaluating the catalyst's performance. The first Claus reactor, second Claus reactor, and reduction reactor are the three reactors that contain a 


\section{Petroleum \& Petrochemical Engineering Journal}

catalyst. Low catalyst performance is indicated by high $\Delta \mathrm{P}$ and low $\Delta \mathrm{T}$. The inlet and outlet temperatures and pressures from the three reactors are shown in Table 6.

\begin{tabular}{|c|c|c|c|c|c|c|c|c|}
\hline Description & Unit & Design & Day1 & Day2 & Day3 & Day4 & Day5 & Day6 \\
\hline \multicolumn{9}{|c|}{ First Claus reactor } \\
\hline Inlet $\mathrm{P}$ & $\mathrm{kg} / \mathrm{cm} 2 \mathrm{~g}$ & 0.51 & 0.06 & 0.06 & 0.05 & 0.04 & 0.06 & 0.05 \\
\hline Outlet P & $\mathrm{kg} / \mathrm{cm} 2 \mathrm{~g}$ & 0.47 & 0.05 & 0.03 & 0.03 & 0.03 & 0.04 & 0.04 \\
\hline$\Delta P$ & $\mathrm{~kg} / \mathrm{cm} 2 \mathrm{~g}$ & 0.04 & 0.01 & 0.03 & 0.02 & 0.01 & 0.03 & 0.02 \\
\hline Inlet $\mathrm{T}$ & ${ }^{\circ} \mathrm{C}$ & 240 & 234.12 & 234.17 & 233.88 & 233.48 & 233.35 & 233.56 \\
\hline Outlet T & ${ }^{\circ} \mathrm{C}$ & 291 & 293.01 & 291.17 & 290.12 & 289.07 & 289.07 & 289.52 \\
\hline$\Delta T$ & ${ }^{\circ} \mathrm{C}$ & 51 & 58.89 & 56.99 & 56.24 & 55.59 & 55.72 & 55.96 \\
\hline \multicolumn{9}{|c|}{ Second Claus reactor } \\
\hline Inlet $\mathrm{P}$ & $\mathrm{kg} / \mathrm{cm} 2 \mathrm{~g}$ & 0.47 & 0.05 & 0.03 & 0.03 & 0.03 & 0.04 & 0.04 \\
\hline Outlet P & $\mathrm{kg} / \mathrm{cm} 2 \mathrm{~g}$ & 0.33 & 0.05 & 0.04 & 0.04 & 0.03 & 0.03 & 0.04 \\
\hline$\Delta P$ & $\mathrm{~kg} / \mathrm{cm} 2 \mathrm{~g}$ & 0.14 & 0.00 & -0.01 & 0.00 & 0.00 & 0.00 & 0.00 \\
\hline Inlet T & ${ }^{\circ} \mathrm{C}$ & 200 & 202.04 & 202.01 & 202.00 & 202.00 & 202.01 & 201.95 \\
\hline Outlet T & ${ }^{\circ} \mathrm{C}$ & 220 & 212.32 & 211.19 & 210.56 & 209.87 & 209.99 & 210.24 \\
\hline$\Delta \mathbf{T}$ & ${ }^{\circ} \mathrm{C}$ & 20 & 10.27 & 9.18 & 8.56 & 7.87 & 7.98 & 8.29 \\
\hline \multicolumn{9}{|c|}{ Reduction reactor } \\
\hline Inlet $\mathrm{P}$ & $\mathrm{kg} / \mathrm{cm} 2 \mathrm{~g}$ & 0.18 & 0.04 & 0.03 & 0.03 & 0.03 & 0.03 & 0.03 \\
\hline Outlet P & $\mathrm{kg} / \mathrm{cm} 2 \mathrm{~g}$ & 0.14 & 0.03 & 0.03 & 0.02 & 0.02 & 0.02 & 0.03 \\
\hline$\Delta P$ & $\mathrm{~kg} / \mathrm{cm} 2 \mathrm{~g}$ & 0.04 & 0.01 & 0.01 & 0.01 & 0.01 & 0.01 & 0.00 \\
\hline Inlet $\mathrm{T}$ & ${ }^{\circ} \mathrm{C}$ & 240 & 238.09 & 236.73 & 236.58 & 235.12 & 234.14 & 234.66 \\
\hline Outlet T & ${ }^{\circ} \mathrm{C}$ & 264 & 241.51 & 238.75 & 238.24 & 236.56 & 235.94 & 238.23 \\
\hline$\Delta T$ & ${ }^{\circ} \mathrm{C}$ & 24 & 3.42 & 2.02 & 1.66 & 1.44 & 1.80 & 3.57 \\
\hline
\end{tabular}

Table 6: Catalyst monitoring for six days.

First Claus reactor: According to the design, the first Claus reactor temperature inlet is 240 degrees Celsius. This temperature is higher than the second Claus reactor's design temperature for performing the hydrolysis reactions of COS and $\mathrm{CS}_{2}$ to convert to $\mathrm{H}_{2} \mathrm{~S}$. Inlet temperatures are around $233^{\circ} \mathrm{C}$ under real operating conditions. As a new guide in temperature evaluation, we can use the real working normal temperature. The outlet temperatures are approximately $291^{\circ} \mathrm{C}$, which is close to the design temperature. Since the reactions are exothermic, the outlet temperature is higher than the inlet temperature. In terms of reactor temperatures, the catalyst is performing well. The difference in pressures reveals values that are lower than those specified in the design. The temperature difference shows values that are higher than the design values, indicating high catalyst reactivity in the Start Of Run phase (SOR).

Second Claus reactor: According to the design, the temperature inlet for the second Claus reactor is 200 degrees Celsius. The Claus reaction can be carried out at this temperature. The inlet temperatures are almost equivalent to the design temperatures, while the outlet temperatures are lower. The average outlet temperature is about 210 degrees Celsius. This isn't a sign that the catalyst isn't working properly. The bulk of the Claus reaction takes place in the first Claus reactor due to the SOR conditions. The reactivity of the first Claus reactor is expected to decrease over time, while the Claus reaction will be conducted more frequently in the second reactor, increasing the outlet temperature.

Reduction reactor: Although the reduction reactor's outlet temperature is lower than anticipated, the reactor is thought to be working properly because the incinerator stack's exit Sulphureous compounds are still within normal limits.

\section{Sulphur Production Calculations}

Sulphur production is calculated in two ways: by measuring the level of the Sulphur production tank and by using laboratory analysis to calculate the material balance as shown in Table 7. 


\begin{tabular}{|c|c|c|c|}
\hline Day & $\begin{array}{c}\text { Sulphur } \\
\text { production by } \\
\text { Tank levels (ton/d) }\end{array}$ & $\begin{array}{c}\text { Sulphur } \\
\text { production by } \\
\text { laboratory (ton/d) }\end{array}$ & $\begin{array}{c}\text { \% } \\
\text { error }\end{array}$ \\
\hline 1 & 299 & 190 & -36.4 \\
\hline 2 & 136 & 232 & 70.7 \\
\hline 3 & 285 & 263 & -7.6 \\
\hline 4 & 288 & 257 & -10.5 \\
\hline
\end{tabular}

Table 7: Sulphur production by tank level and laboratory analysis.

Sulphur output calculated from tank levels differs from production calculated from material balance based on laboratory samples every time. The estimate based on increasing Sulphur output tank levels is right. Sour water striper units and Amine regenerator units provide the bulk of the feed to the SRU unit. SWS1, SWS2, ARU1, and ARU2 provide the complete feed to the SRU. Sulphur mass balances based on $\mathrm{H}_{2} \mathrm{~S}$ concentrations in SWS and ARU units are commonly used in laboratory output calculations. The differences between the two calculations on four different days are as follows: $(-36.4 \%, 70.7 \%,-7.6 \%$ and $-10.5 \%)$. Figure 11 depicts the actual figure for the mass balance measured using SWS1's laboratory analysis.

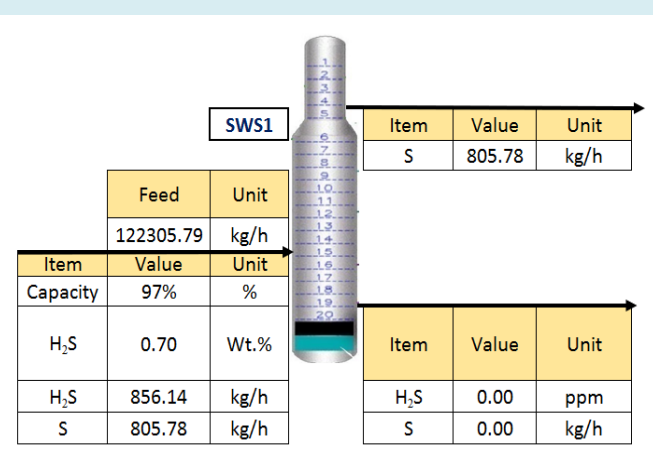

Figure 11: SWS1 material balance based on laboratory analysis.

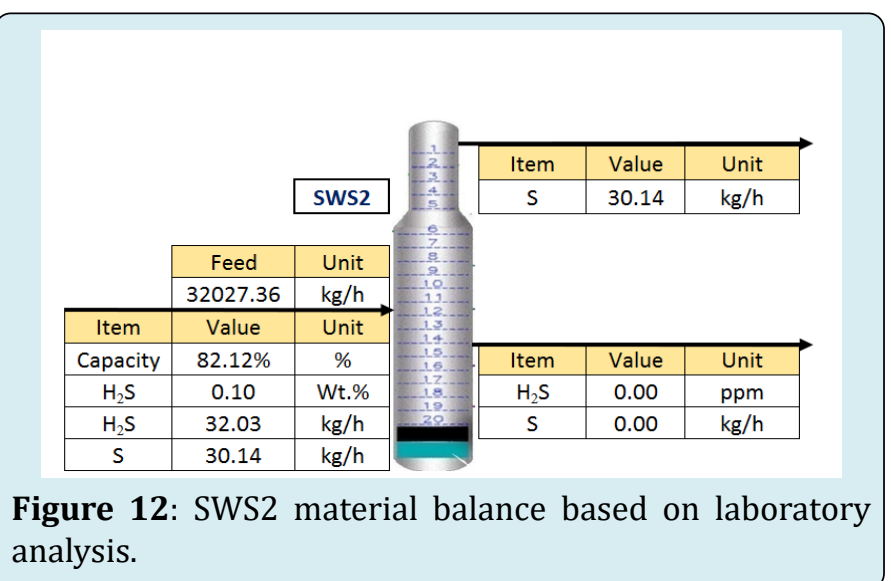

Figure 12 shows an actual figure for the mass balance calculated based on the laboratory analysis of SWS2.

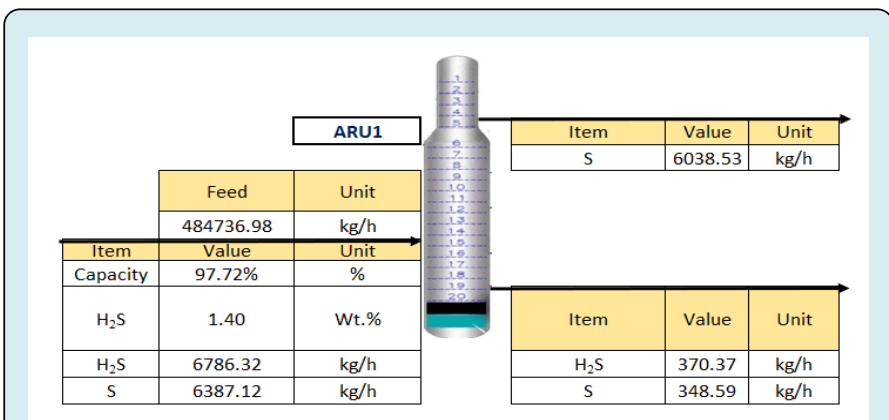

Figure 13: ARU1 material balance based on laboratory analysis.

Figure 13 shows an actual figure for the mass balance calculated based on the laboratory analysis of ARU1.

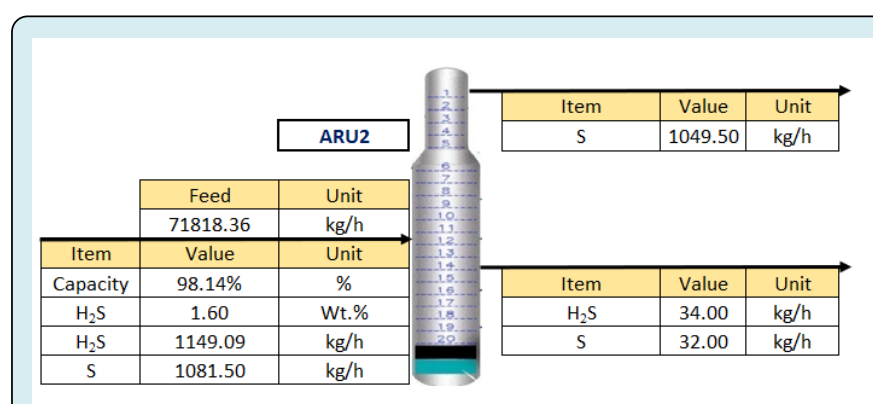

Figure 14: ARU2 material balance based on laboratory analysis.

Figure 14 shows an actual figure for the mass balance calculated based on the laboratory analysis of ARU2.

The total Sulphur balance is the sum of the output from the SWS1, SWS2, and ARU1, ARU2 towers' overheads. Figure 15 represents the SRU's total Sulphur mass balance.

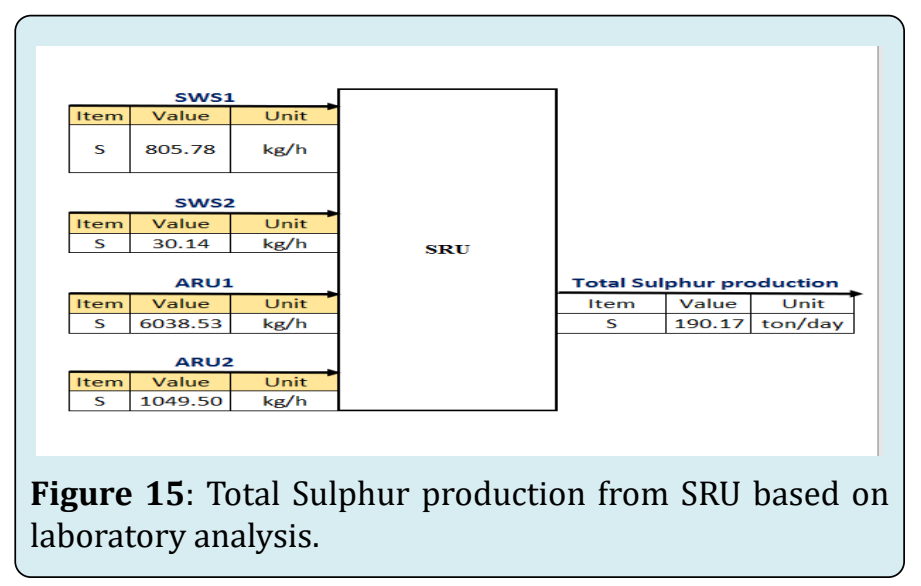




\section{Petroleum \& Petrochemical Engineering Journal}

Figure 16 shows the percentage share of each unit in Sulphur production

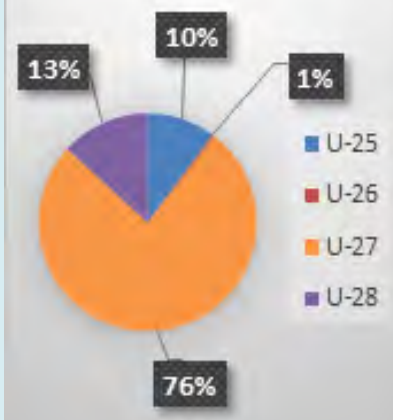

Figure 16: Percentage share of each unit in Sulphur production.

\section{Summary and Conclusions}

All acid gas is treated to elemental Sulphur in a Sulphur recovery unit at a refining plant in the Middle East, which started official production in 2020. Because of strict environmental laws, acid gas cannot be released into the atmosphere. The plant was simulated using a special Sulphur package in HYSYS called SULSIM to evaluate some key parameters. After simulation validation, one of the most important keys, the $\left(\mathrm{H}_{2} \mathrm{~S} / \mathrm{SO}_{2}\right)$ ratio, was tested. The ideal ratio is two. Any deviation from this ratio causes significant process problems, such as catalyst ageing in the reactors. In a case study, the impact of lowering the ratio from 2 to 0.22 was investigated. The temperature of the reduction reactor's outlet increased from $279.73^{\circ} \mathrm{C}$ to $314.34^{\circ} \mathrm{C}$, which was higher than normal. Natural gas is used to heat the process in Start-up mode until it reaches the proper temperature in the reaction furnace, which is $1350^{\circ} \mathrm{C}$. The reaction furnace is then fed with acid gases without the TGTU section being lined up.

The reduction reactor can be lined up after the ratio $\left(\mathrm{H}_{2} \mathrm{~S} / \mathrm{SO}_{2}\right)$ has been adjusted to 2. After converting from natural gas to acid gas mode, the $\left(\mathrm{H}_{2} \mathrm{~S} / \mathrm{SO}_{2}\right)$ ratio takes a long time to adapt to 2 . The switching time between adding the acid gas to the Claus and lining up the TGT took 6, 11, 14 , and 24 hours in four real start-ups. When evaluating the catalyst's efficiency, the difference in pressures and temperatures between the reactor inlets and outlets are the two most important parameters to consider. The three reactors that contain a catalyst are the first Claus reactor, second Claus reactor, and reduction reactor. High $\Delta \mathrm{P}$ and low $\Delta \mathrm{T}$. The temperature difference in the first Claus reactor is higher than the design values $\left(59^{\circ} \mathrm{C}\right.$ versus $\left.51^{\circ} \mathrm{C}\right)$, suggesting high catalyst reactivity in the Start Of Run (SOR). The average outlet temperature in the second Claus reactor is about $210^{\circ} \mathrm{C}$ versus $220^{\circ} \mathrm{C}$ design. This is not an indication that the catalyst is malfunctioning. Because of the SOR conditions, the majority of the Claus reaction takes place in the first Claus reactor. The first Claus reactor's reactivity is predicted to decrease over time, while the Claus reaction in the second reactor would occur more frequently, increasing the outlet temperature. Even though the reduction reactor's outlet temperature is lower than anticipated, the reactor is believed to be functioning properly because the incinerator stack's exit Sulphur compounds are still within normal limits. Sulphur production can be calculated in two ways: by measuring the level of the Sulphur production tank and by calculating the material balance using laboratory analysis. Every time, sulphur production based on tank levels vary from production based on material balance based on laboratory samples. The calculations based on rising Sulphur production tank levels are accurate. The following are the variations between the two calculations on four different days: $(-36.4 \%, 70.7 \%,-7.6 \%$, and $-10.5 \%)$.

\section{References}

1. Khatami A, Heidari Y, Safadoost A, Aleghafouri A, Davoudi M (2016) The activity loss modeling of catalytic reactor of sulfur recovery unit in South Pars Gas Complex (SPGC) 3 rd refinery based on percolation theory. Journal of Natural Gas Science and Engineering 28: 723-736.

2. Mahmoodi B, Hosseini SH, Ahmadi G, Raj A (2017) CFD simulation of reactor furnace of sulfur recovery units by considering kinetics of acid gas (H2S and CO2) destruction. Applied Thermal Engineering 123: 699710.

3. Lavery CB, Marrugo-Hernandez JJ, Sui R, Dowling NI, Marriott RA (2019) The effect of methanol in the first catalytic converter of the Claus sulfur recovery unit. Fuel 238: 385-393.

4. Ibrahim AY, Ashour FH, Gadallah MA (2021) Exergy Study of Amine Scrubber Unit of a Sulphur Recovery Plant using Methyl Diethanolamine: A Real Starting up Plant. Petroleum and Coal 63(1): 155-165.

5. Ibrahim AY, Ashour FH, Gadallah MA (2021) Exergy Study of Amine Regeneration Unit Using Diethanolamine in a Refinery plant: A Real Start-Up Plant. Heliyon 7(2): e06241.

6. Abdoli P, Hosseini SA, Mujeebu MA (2019) Effect of Preheating Inlet Air and Acid Gas on the Performance of Sulfur Recovery Unit-CFD Simulation and Validation. Forschung im Ingenieurwesen 83(1): 81-89. 


\section{Petroleum \& Petrochemical Engineering Journal}

7. Sui R, Lavery CB, Li D, Deering CE, Chou N, et al. (2019) Improving low-temperature CS2 conversion for the Claus process by using La (III)-doped nanofibrous $\mathrm{TiO} 2$ xerogel. Applied Catalysis B: Environmental 241: 217226.

8. Ibrahim S, Rahman RK, Raj A (2017) Effects of H2O in the feed of sulfur recovery unit on sulfur production and aromatics emission from Claus furnace. Industrial \& Engineering Chemistry Research 56(41): 11713-11725.

9. Hosseini SM, Alizadeh R, Alizadehdakhel A, Behjat Y, Nooriasl P (2019) Enhancement of gas distribution uniformity in a claus process catalytic reactor using computational fluid dynamics. Chemical Engineering and Processing-Process Intensification 144: 107653.

10. Rostami A, Tavan Y (2019) A survey on exergy, energy and environmental analysis of sulfur recovery unit in case of five intensified configurations. Chemical Papers 73(6): 1529-1539.

11. Kazempour H, Pourfayaz F, Mehrpooya M (2017) Modeling and multi-optimization of thermal section of Claus process based on kinetic model. Journal of Natural Gas Science and Engineering 38: 235-244.

12. Mehmood A, Alhasani H, Alamoodi N, AlWahedi YF, Ibrahim S, et al. (2020) An evaluation of kinetic models for the simulation of Claus reaction furnaces in sulfur recovery units under different feed conditions. Journal of Natural Gas Science and Engineering 74: 103106.

13. Ghahraloud H, Farsi M, Rahimpour MR (2017) Modeling and optimization of an industrial Claus process: Thermal and catalytic section. Journal of the Taiwan Institute of Chemical Engineers 76: 1-9.

14. Al-Jamimi HA, BinMakhashen GM, Deb K, Saleh TA (2021) Multiobjective optimization and analysis of petroleum refinery catalytic processes: A review. Fuel 288: 119678.

15. Minier-Matar J, Janson A, Hussain A, Adham S (2017) Application of membrane contactors to remove hydrogen sulfide from sour. Journal of Membrane Science 541: 378-385.

16. Gai H, Chen S, Lin K, Zhang X, Wang C, et al. (2020) Conceptual design of energy-saving stripping process for industrial sour water. Chinese Journal of Chemical Engineering 28(5): 1277-1284.

17. Dardor D, Janson A, AlShamari E, Adham S, Minier-Matar J (2020) The effect of Hydrogen sulfide oxidation with ultraviolet light and aeration on sour water treatment via membrane contactors. Separation and Purification
Technology 236: 116262.

18. Zahid Z (2019) Techno-economic evaluation and design development of sour water stripping system in the refineries. Journal of Cleaner Production 236: 117633.

19. Zhu M, Sun L, Ou G, Wang K, Wang K, et al. (2016) Erosion corrosion failure analysis of the elbow in sour water stripper overhead condensing reflux system. Engineering Failure Analysis 62: 93-102.

20. Hassan-Beck H, Firmansyah T, Suleiman MI, Matsumoto T, AL-Musharfy M, et al. (2019) Failure analysis of an oil refinery sour water stripper overhead piping loop: Assessment and mitigation of erosion problems. Engineering Failure Analysis 96: 88-99.

21. Amini J, Davoodi A, Jafari H (2018) Analysis of internal cracks in Type 304 austenitic stainless steel cladding wall of regenerator column in amine treating unit. Engineering Failure Analysis 90: 440-450.

22. Wang M, Hariharan S, Shaw RA, Hatton TA (2019) Energetics of electrochemically mediated amine regeneration process for flue gas $\mathrm{CO} 2$ capture. International Journal of Greenhouse Gas Control 82: 4858.

23. Abdolahi-Mansoorkhani $\mathrm{H}$, Seddighi $\mathrm{S}$ (2019) $\mathrm{H}_{2} \mathrm{~S}$ and $\mathrm{CO}_{2}$ Capture from Gaseous Fuels using Nanoparticle Membrane. Energy 168: 847-857.

24. Mohamadi-Baghmoleaei M, Hajizadeh A, Zahedizadeh $P$, Azin R, Zendehboudi S (2020) Evaluation of Hybridized Performance of Amine Scrubbing Plant Based on Exergy Energy, Environmental, and Economic Prospects: A Gas Sweetening Plant Case Study. Energy 214: 118715.

25. Pashaei $\mathrm{H}$, Ghaemi A (2020) $\mathrm{CO}_{2}$ absorption into aqueous diethanolamine solution with nano heavy metal oxide particles using stirrer bubble column: Hydrodynamics and mass transfer. Journal of Environmental Chemical Engineering 8(5): 104110.

26. Aghel B, Sahraie S, Heidaryan E (2019) Carbon dioxide desorption from aqueous solutions of monoethanolamine and diethanolamine in a microchannel reactor. Separation and Purification Technology 237: 116390.

27. Concepción EI, Moreau A, Martín MC, Vega-Maza D, Segovia JJ (2020) Density and viscosity of aqueous solutions of Methyldiethanolamine (MDEA) + Diethanolamine (DEA) at high pressures. The Journal of Chemical Thermodynamics 148: 106141.

28. Shunji K, Xizhou S, Wenze Y (2020) Investigation of $\mathrm{CO}_{2}$ desorption kinetics in MDEA and MDEA+DEA rich amine 
solutions with thermo-gravimetric analysis method. International Journal of Greenhouse Gas Control 95: 102947.

29. Pal P, AbuKashabeh A, Al-Asheh S, Banat F (2015) Role of aqueous methyldiethanolamine (MDEA) as solvent in natural gas sweetening unit and process contaminants with probable reaction pathway. Journal of Natural Gas Science and Engineering 24: 124-131.

30. Ibrahim AY (2021) Performance Assessment of a Sulphur Recovery Unit. Petroleum and Petrochemical Engineering Journal 5(1): 1-9. 